\title{
Prediction and Mapping of the Impact of Winter Temperature on the Development of Phytophthora cinnamomi-Induced Cankers on Red and Pedunculate Oak in France
}

\author{
Benoit Marçais, Magali Bergot, Victorine Pérarnaud, André Levy, and Marie-Laure Desprez-Loustau
}

First author: INRA-Nancy, Laboratoire de Pathologie Forestière, 54280 Champenoux; second and third authors: Météo-France, Service Central d'Exploitation de la Météorologie; fourth author: Ministère de l'Agriculture, Département de la Santé des Forêts; and fifth author: INRA-Bordeaux, Laboratoire de Pathologie Forestière. Accepted for publication 19 March 2004.

\begin{abstract}
Marçais, B., Bergot, M., Pérarnaud, V., Levy, A., and Desprez-Loustau, M.-L. 2004. Prediction and mapping of the impact of winter temperature on the development of Phytophthora cinnamomi-induced cankers on red and pedunculate oak in France. Phytopathology 94:826-831.

Phytophthora cinnamomi is the causal agent of a perennial canker that develops on the lower bole on northern red oak and pedunculate oak. The disease has a limited range in Europe, being reported only in southwest France. This limited distribution is probably linked to the susceptibility of $P$. cinnamomi to frost. A model was developed in previous work to estimate the impact of temperatures of $<0^{\circ} \mathrm{C}$ on the winter survival of $P$. cinnamomi in trunk cortical tissues and on the subsequent development of cankers. In this article, we report the use of this model to simulate canker development in 503 locations across France during a 30-year period. The predicted canker extension decreased sharply when the median P. cinna-
\end{abstract}

ABSTRACT momi winter survival index decreased from 0.95 to 0.65 , with cankers that poorly developed when the median survival index was lower than 0.5 to 0.6. The actual incidence of the disease in 192 stands located across southwest France was compared with that of the model outputs. Both presence of disease in stands and frequency of cankered trees in infected stands, but not canker size on infected trees, were strongly related to the median P. cinnamomi survival index. No disease was present in stands with median survival index lower than 0.65 , and the frequency of cankered trees in infected stands remained very low in stands with a median survival index between 0.65 and 0.70 . Aspect was an additional factor explaining disease incidence, while the effect of elevation was likely due to its effect on winter temperatures. Maps of winter suitability to $P$. cinnamomi-induced cankers on oaks in France are presented.

Additional keywords: Quercus robur, Q. rubra.
Northern red oak, Quercus rubra L., an exotic tree species in Europe, has been extensively planted in southwest France during the 20th century, in part to replace stands impacted by exotic pathogens introduced at the beginning of the century. In particular, black oak, $Q$. pyrenaica Willd, was severely impacted by powdery mildew, Microsphaera alphitoides Griffon et Maublanc (8), and sweet chestnut, Castanea sativa Mill. by Phytophthora cinnamomi Rands (1). Indeed, Q. rubra was reported as tolerant to European powdery mildew and not affected by $P$. cinnamomi in its natural distribution area $(6,18)$. In the early 1950s, the ink disease of northern red oak, induced by P. cinnamomi, was described in the Basque area around Biarritz $(1,16)$. In infected stands, as much as 30 to $40 \%$ of the trees can be infected (11). The disease has since also become a problem on $Q$. robur, the indigenous pedunculate oak, especially in young stands that have been planted (15). Presence of ink disease on pedunculate oak is especially worrying, because this species is much more important than northern red oak in Europe both economically and ecologically. It is feared that the disease has been introduced into planted stands with infected seedlings and that it might be presently spreading on a large scale by infected nursery stock. The main symptom of the disease on red and pedunculate oak is a bleeding canker on the lower bole of the tree that can reach up to 4 to $5 \mathrm{~m}$

Corresponding author: B. Marçais; E-mail address: marcais@ nancy.inra.fr

Publication no. P-2004-0603-02R

This article is in the public domain and not copyrightable. It may be freely reprinted with customary crediting of the source. The American Phytopathological Society, 2004. high. The canker drastically reduces the value of the timber. Although the pathogen infects the trees via roots and attacks the fine roots, $P$. cinnamomi does not appear to affect the general health of the trees, at least for red oak. Infected trees do not appear to decline and their radial growth is not reduced (21). The development of the canker can be studied retrospectively by dendrochronological methods, and cankered trees with apparently healthy crowns were shown to have been infected for several decades $(14,21)$. This contrasts strongly with the situation that has been described for other oak species and for chestnuts where $P$. cinnamomi induces a decline presumably because the infection of the root system is more severe $(3,6,23)$. In the south of France, $P$. cinnamomi also causes ink disease on Mediterranean oak species, $Q$. ilex and $Q$. suber, inducing either trunk cankers or decline symptoms $(3,20)$. However, because our work focuses on red oak, ink disease will here refer only to the presence of cankers.

About 50 years after its first mention, ink disease of red and pedunculate oak is still present only in a small part of southwest France and adjacent areas of Spain, mainly in the Pyrenean Piedmont, in an area where it was probably already present in the 1950s $(10,11,14)$. This is in contrast with the rapid extension reported for the ink disease of chestnuts, caused by the same pathogen, from its first report in 1848 in the Basque country $(9,17)$. Ink disease has since been reported on chestnuts in most areas where this species is present, in places where, despite widespread occurrence of pedunculate and red oaks, no ink disease was reported on those species. P. cinnamomi has also been reported on various ornamental plants in a large part of the country, far beyond the limited area in which the ink disease of $Q$. rubra 
can be found in natural conditions (25). Delatour (7) hypothesized that the high susceptibility of $P$. cinnamomi to frost might explain the geographic distribution of the disease. Indeed, the parasite has a limited survival at temperatures below $0^{\circ} \mathrm{C}(2,22)$, and cold winters were shown to have a major impact on canker development in infected red oak stands of southwest France (14). A lower impact of frosts is expected on hosts such as chestnut and ornamental plants where $P$. cinnamomi causes primarily a root disease, because deep layers of the soil seldom freeze in France.

A model was developed that describes the influence of frost on the winter survival of $P$. cinnamomi in the trunk cortical tissues of the host (12). The model outputs were in good agreement with the annual development of natural cankers in red oaks (14). In particular, it was shown that the pathogen may be eliminated from cankers during exceptionally severe frosts with subsequent total healing of cankers. This suggests that once $P$. cinnamomi is present in a site, the development of a perennial canker is strongly dependent on the local winter climate. However, if the model predicts the influence of pathogen overwintering for single winters, we need to be able to assess the integrated impact of successive winters on the enlargement of these perennial cankers that develop over several decades.

The aim of this work was to extrapolate the previous model over long periods by simulations of canker development in order to determine which winter temperature regimes are favorable to the ink disease of red oak. Model outputs were also compared with the actual distribution of ink disease of oak in southwest France in order to validate the method. Finally, a climatic hazard map for ink disease on oaks was constructed.

\section{MATERIALS AND METHODS}

Mapping of pathogen survival. $P$. cinnamomi winter survival indices $\left(I_{n}\right)$ were computed for each year from 1969 to 1998 for the 503 meteorological stations of France from the Météo-France network having 30 years of temperature data and an elevation of $<1,000 \mathrm{~m}$. $I_{n}$ was computed as a function of the annual sum of temperature below $0^{\circ} \mathrm{C}$ in the bark, as explained in Marçais et al. (14). Bark temperatures were computed hourly from air temperatures using a thermal transmission coefficient that represents the proportion of the air temperature variations, which is transmitted to the bark, and the sum of temperatures $<0^{\circ} \mathrm{C}$ in the bark was computed from those values. The calculation was done for the southern facing part of a large red oak tree of 50-cm-trunk diameter to be conservative, because $I_{n}$ increases with tree size and is larger on the southern aspect of the trunk. $I_{n}$ values were computed for the same stations and the same period for pedunculate oak. The bark transmission coefficients used for red oak were 0.48 and 0.30 for unfrozen bark and frozen bark, respectively (14). Lower bark transmission coefficients of 0.16 and 0.07 for unfrozen and frozen bark, respectively, were used for pedunculate oak, due to the different bark structure (B. Marçais, unpublished data). Median $I_{n}$ values across years were then calculated for each meteorological station and oak species. These parameters were mapped using the GIS Arcview software (Environmental Systems Research Institute, Redford, CA), with a $4 \times 4 \mathrm{~km}$ grid. The value for each grid point was computed as the mean of the five nearest meteorological stations weighted by $1 / d^{2}, d$ being the distance between the grid point and the station.

Influence of winter temperature on canker enlargement. To determine whether a canker will develop on an oak tree under a given winter temperature regime if $P$. cinnamomi is present at the tree base, we used data from Marçais et al. (14). In this previous study, the enlargement of natural cankers was studied retrospectively for about 25 years, using the symptoms of past cambium infections left in the wood, and was compared with the annual $P$. cinnamomi survival index, $I_{n}$, computed for each tree. The data were here reanalyzed to simulate canker enlargement in a given winter temperature regime. The canker development was described as follows:

$$
P_{n}=a+b \times \log \left(I_{n} \times P_{n-1}\right) \times I_{n} \times P_{n-1}
$$

with $P_{n}$ the width of trunk perimeter attacked at the cambium level in year $n$ (in centimeters) and $a+b \times \log \left(I_{n} \times P_{n-1}\right)$ the canker growth rate. $I_{n} \times P_{n-1}$ represents the proportion of the previous year's canker lesions where $P$. cinnamomi is still active in the spring. The density-dependence of canker growth was described by the relation $a+b \times \log \left(I_{n} \times P_{n-1}\right)$, and the parameters $a$ and $b$ were estimated by non-linear regression by the GaussNewton method using the procedure NLIN of SAS (SAS/STAT 6.0, SAS Institute, Cary, NC) based on the data reported in Marçais et al. (14).

The ability of $P$. cinnamomi to induce a canker on an oak tree, provided it is present in soil at the base of the tree, was then estimated across France using the 503 series of 30 annual $I_{n}$ values computed in the previous section. At the beginning of the period, in $1969, P_{n}$ was set to 1 , which is close to the value observed the first year of infection for a sample of naturally infected trees (14), and equation 1 was used to simulate the canker extension. Whenever $P_{n}$ reached a value of $<1$, it was reset to 1 to take into account the possible initiation of new cankers from root or collar infections. The maximal enlargement reached by the cankers during the 30-year period was then related to the median $I_{n}$.

Validation data. During the period 1990 to 1994, 192 red oak stands located in the southwest of France were surveyed for incidence of ink disease by technicians of the Département de la Santé des Forêts, the French forest health survey. The stands were selected in two ways depending on the location. In the PyrénéesAtlantiques and Hautes-Pyrénées, where red oak is frequent and the disease known to be widespread, about one $>20$-year-old stand was sampled for each 10 ha of red oak forest, taking care in each forest, whenever possible, to select stands in all aspects and all topographic positions. In the rest of the area, all known $>20$-yearold stands were selected for the study. In each stand, 30 to 100 trees, depending on stand size, were examined for ink disease symptoms, i.e., a typical bleeding canker starting at the bottom of the tree. Each tree was rated as 0 , no canker; 1, canker $<1 \mathrm{~m}$ above ground; 2, canker 1 to $2 \mathrm{~m}$ above ground; 3, canker $>2 \mathrm{~m}$ above ground. An index of canker development for infected trees of each stand was computed as $\mathrm{CD}=\left(0.5 \times N_{1}+1.5 \times N_{2}+2.5 \times\right.$ $\left.N_{3}\right) /\left(N_{1}+N_{2}+N_{3}\right)$, where $N_{i}$ is the number of trees with a disease rating of $i$ in the stand. The coefficients $0.5,1.5$, and 2.5 correspond to the mean canker height of disease rating 1,2 , and 3 . This index is proportional to the volume loss on infected trees due to the canker.

In each stand, coordinates in longitude and latitude, elevation, topography, and slope aspect as north to northwest, west to southwest, south to southeast, east to northeast, and no slope were noted. This survey has been reported elsewhere $(10,11)$ and more information on relationships between ink disease and site conditions can be found in those reports. The results of this survey showing the distribution of ink disease on oaks in southwest France are presented in Figure 1. The disease has not been reported from other areas so far.

Model validation. The $I_{n}$ values computed in the previous section for 1969 to 1994 and for the 503 meteorological stations of France were used to compute the 26 annual $I_{n}$ values by kriging for each of the 192 red oak stands surveyed for presence of ink disease. Data for years 1995 to 1998 were not used because the stand survey was done in 1990 to 1994. The data from all meteorological stations were used to establish the variograms, while the data from the 87 meteorological stations that were located in southwest France were used for kriging. The variograms were modeled by spherical functions. The computations were done in BLUEPACK software (Delfiner, Delhomme, Chiles, Ecole des mines de Paris). The median $I_{n}$ was computed for each surveyed stand. 
The relationship between median $I_{n}$ and presence/absence of ink disease in a stand, called hereafter presence of disease in stands, was analyzed by logistic regression using the GENMOD procedure of SAS. A similar analysis was conducted for the frequency of cankered trees in stands where the disease was present. The model used was the following: $\log \left[p_{i} /\left(1-p_{i}\right)\right]=\mu+\alpha \times$ elevation $_{i}+\beta \times$ median $I_{i}+\gamma \times$ aspect $_{i}+\rho \times$ median $_{i} \times$ aspect $_{i}$, where $p_{i}$ is the likelihood of either disease presence in a stand or canker presence on a tree. Model validity was checked using the deviance/degree of freedom ratio when group binary data were analyzed, by plotting deviance residuals against the linear predictor, and by using a half-normal plot (5). The model for the frequency of cankered trees in stands with presence of the disease showed some overdispersion, evidenced by a ratio deviance/degree of freedom higher than expected, and thus the model was fitted

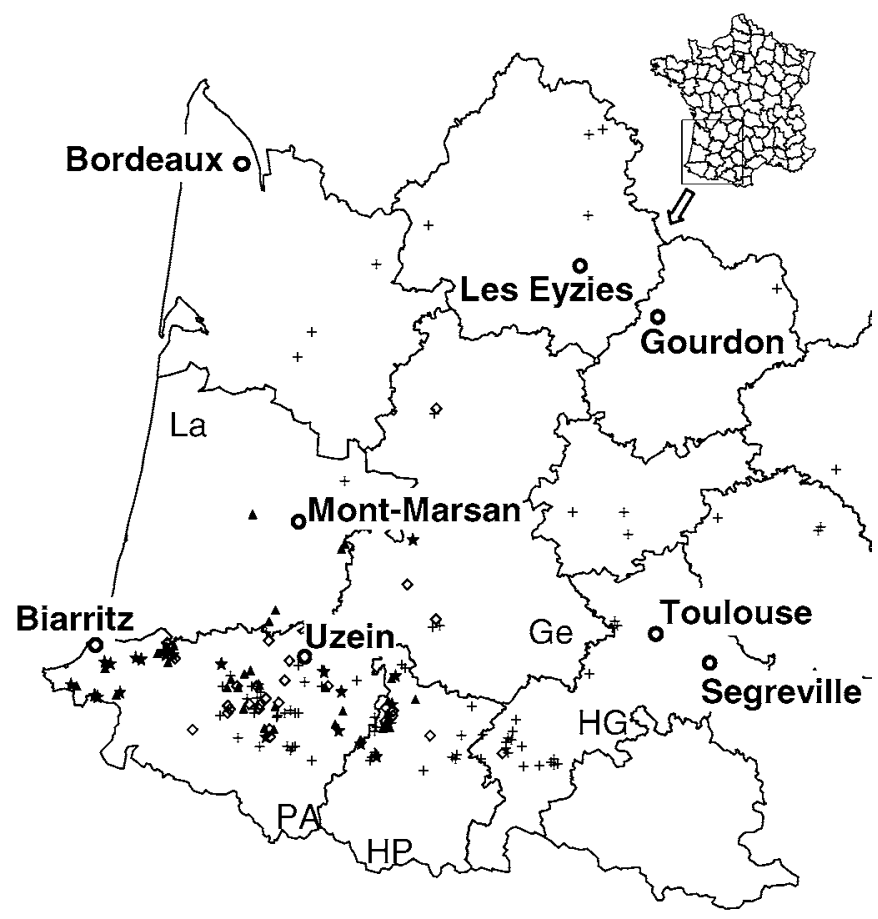

Fig. 1. Distribution of ink disease caused by Phytophthora cinnamomi on red oak in the southwest of France. PA, Pyrénées-Atlantiques; HP, HautesPyrénées; HG, Haute-Garonne; Ge, Gers; La, Les Landes. Frequency of cankered trees: + , none; $\diamond, 1$ to $3 \%$; $\mathbf{\Delta}, 3$ to $10 \%$; and $\star,>10 \%$.

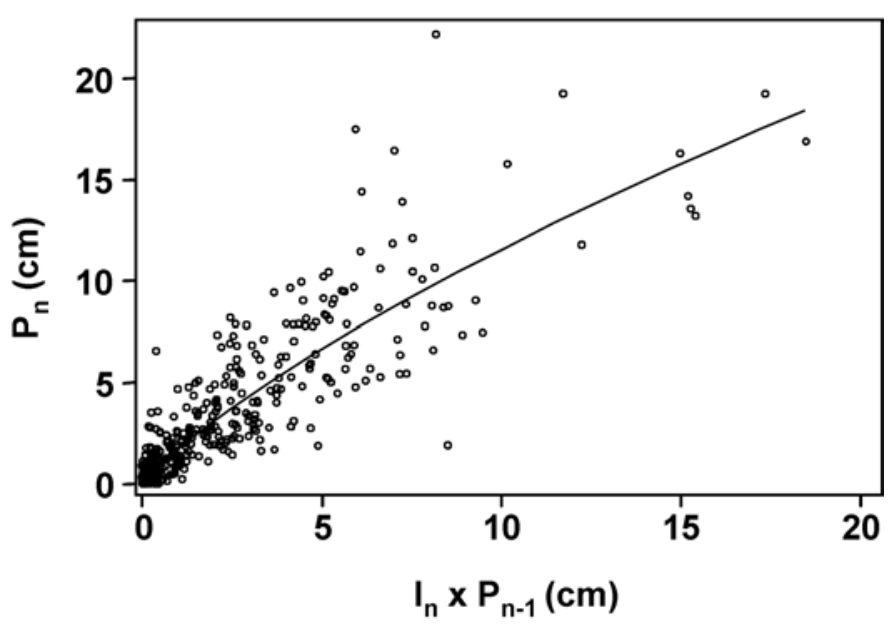

Fig. 2. Relation between canker size at the end of year $n, P_{n}$, and canker size at the end of the previous winter $I_{n} \times P_{n-1}$. The line represents the relation $P_{n}=\left[1.69-0.22 \times \log \left(I_{n} \times P_{n-1}\right)\right] \times I_{n} \times P_{n-1}\left(r^{2}=0.743, P<0.001\right)$. with an overdispersion parameter of 0.056 computed according to the method of Williams (5).

The relationship between the index of canker development, $\mathrm{CD}$, and median $I_{n}$ was studied by regression analysis.

\section{RESULTS}

Influence of winter temperature on canker enlargement. The relationship between the canker size in year $n$ and its size in year $n-1$ was $P_{n}=\left[1.69-0.22 \times \log \left(I_{n} \times P_{n-1}\right)\right] \times I_{n} \times P_{n-1}\left(r^{2}=\right.$ $0.743 ; P<0.001)$. Figure 2 shows the relationship between $P_{n}$ and $I_{n} \times P_{n-1}$.

The simulation of canker enlargement in six contrasted sites of southwest France over the period 1969 to 1998 is shown in Figure 3. In Biarritz, located in the Basque area, winter temperatures are almost never limiting for the disease. The limitation of canker development by poor overwintering was more frequent in stations located farther from Biarritz, and in Gourdon and Les Eyzies, cankers were poorly developed. The main limitation to canker enlargement was not severe frosts with $I_{n}<0.05$, which kill the pathogen in all the cankers as those occurred in the six locations only in 1969 to 1971 and 1985 to 1987 . A 20-year period with little frost limitation was enough in locations like Uzein and Mont-Marsan for significant cankers to develop. By contrast, years with moderate survival with $I_{n}$ in the 0.3 to 0.5 range efficiently hampered the canker enlargement in Segreville and Gourdon in the 1975 to 1984 period. Indeed, a small canker of $P_{n}=1$ will enlarge only if $\left[1.69-0.22 \times \log \left(I_{n}\right)\right] \times I_{n}$ is larger than 1 , i.e., for values of $I_{n}>0.55$. Accordingly, the largest $P_{n}$ reached during the simulation in the 503 locations studied across France decreased quickly when median $I_{n}$ decreased from 0.9 to 0.6 (Fig. 4). When median $I_{n}$ was lower than 0.5 to 0.6 , cankers were poorly developed, with maximal extension $<2$, which means they did not even double in size in a 30-year period compared with the initial value.

Relation between incidence of ink disease in surveyed red oak stands and $P$. cinnamomi survival index. The median $I_{n}$ was significantly linked to both the presence of disease in stands and the frequency of cankered trees in infected stands (Tables 1 and 2). No ink disease was found in the stands where median $I_{n}$ was lower than 0.65. By contrast, disease was present in all of the 12 stands with a median $I_{n}$ of $>0.95$. The relationship between median $I_{n}$ and the frequency of cankered trees in infected stands was less favorable, and still 8 to $14 \%$ of the trees were cankered

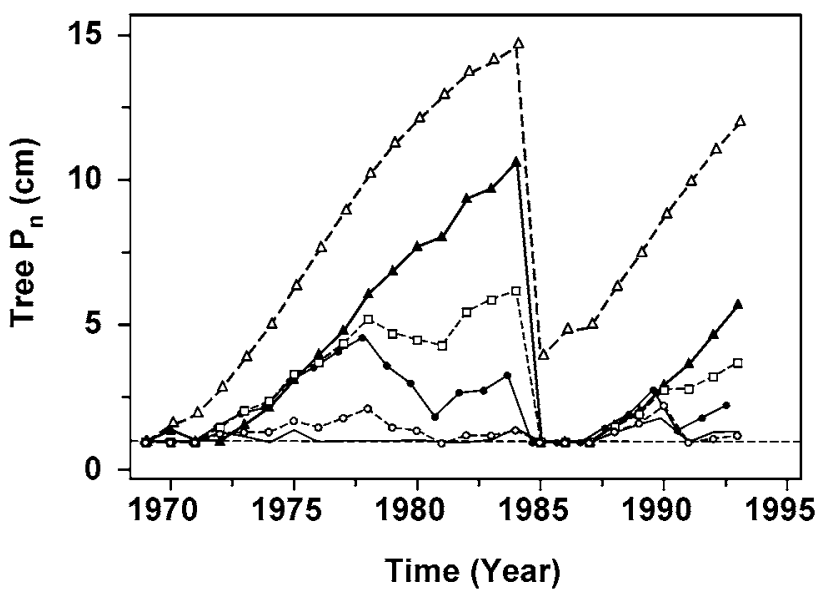

Fig. 3. Simulation of the development of Phytophthora cinnamomi-induced cankers on red oak in six weather stations of southwest France with different

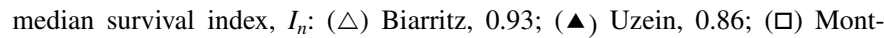
Marsan, 0.78; (•) Segreville, 0.76; (○) Gourdon, 0.61; and $(-)$ Les Eyzies, 0.46. $P_{n}$, the canker size in year $n$ was computed as $P_{n}=[1.69-0.22 \times$ $\left.\log \left(P_{n-1} \times I_{n}\right)\right] \times P_{n} \times I_{n}$, with $P_{n}=1$ at the beginning of the simulation. 
in the infected stands with a median $I_{n}$ of 0.7 to 0.8 . However, stands with the highest median $I_{n}(>0.95)$ had a high percentage of infected trees (22\% compared with 6 to $14 \%$ in the other classes).

Other factors known to be linked to ink disease incidence, such as aspect and elevation (11), were tested to determine whether impact of winter temperature on overwintering of $P$. cinnamomi in trunk tissues could act as a confounding factor in the relationship. The aspect of stands was significantly associated with both presence of the disease in stands and frequency of cankered trees in infected stands, even when median $I_{n}$ was already in the model (Table 2). Stands with an aspect toward the south, west and southwest, and south and southeast had both a higher frequency of ink disease presence and a higher incidence of cankered trees in infected stands (Table 3 ). There was no median $I_{n}$-aspect interaction for these two disease variables. When entered in a model not including median $I_{n}$, elevation was significantly linked to both the presence of ink disease in a stand and the frequency of cankered trees in infected stands $\left(\chi^{2}=31.1\right.$ and 28.0, respectively, $P<0.001)$. However, when it was entered in a model already including the median $I_{n}$ and the stand aspect, it did not contribute any additional information (Table 2).

Unlike the presence of disease in stands or the frequency of cankered trees, disease severity on infected trees, estimated by the mean index of canker development, $\mathrm{CD}$, depended neither on median $I_{n}$ nor on stand aspect (Tables 1 and 3). Pearson's correlation between $\mathrm{CD}$ and median $I_{n}$ was $0.054(P=0.592)$. CD

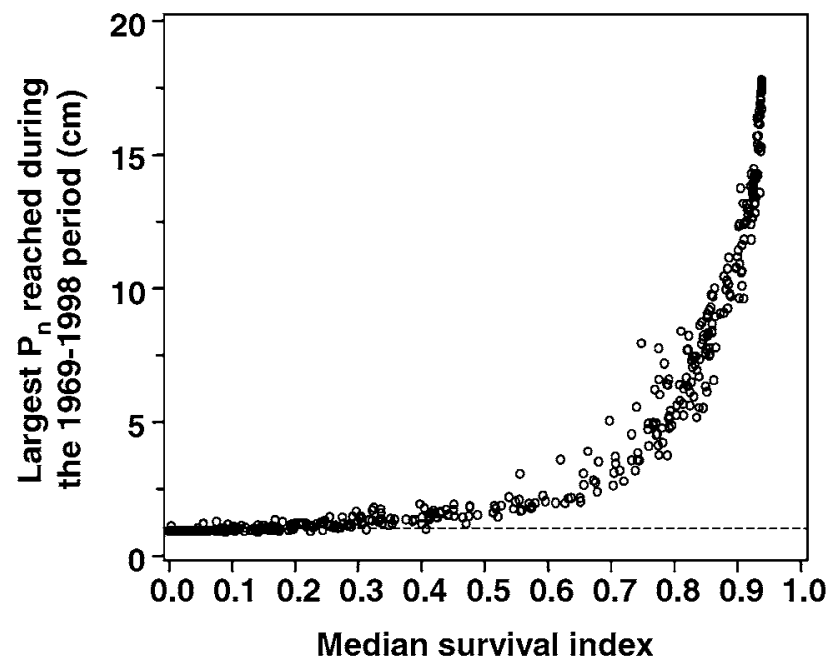

Fig. 4. Relation between maximal canker size on red oak reached during the simulation and median Phytophthora cinnamomi survival index, $I_{n}$, in the 30 -year period (1968 to 1998) for 503 meteorological stations in France. $I_{n}$ is an index indicating overwinter survival of $P$. cinnamomi in oak cortical tissues. remained around 1, which meant that most infected trees had a canker between 0.5 and $1 \mathrm{~m}$ high.

Mapping of pathogen survival in cankers. The map of median $I_{n}$ distribution in France for red oak is shown in Figure 5A. The areas with winter temperature regime favorable to pathogen survival correspond to western and southern coastal areas of the country with median $I_{n}>0.7$. In three areas, winter temperature regime is extremely favorable (median $I_{n}>0.9$ ). They correspond to the actual area of the disease in the southwest corner of the country, to Brittany in the northwest of France, an area free of the disease until now, and to the Mediterranean coast, where $P$. cinnamomi is present on other oak species. The ink disease hazard is very low in most of the rest of the country, with $I_{n}$ above 0.5 . The map for pedunculate oak is different (Fig. 5B), with larger areas with winter temperature regime favorable to canker development (high $I_{n}$ ).

TABLE 2. Relationship between presence of ink disease in the studied stands or frequency of cankered trees in the infected stands and aspect, elevation, and median Phytophthora cinnamomi survival index ${ }^{\mathrm{a}}$

\begin{tabular}{lcrrrrr}
\hline & & \multicolumn{2}{c}{$\begin{array}{c}\text { Presence of } \\
\text { ink disease }\end{array}$} & & \multicolumn{2}{c}{$\begin{array}{c}\text { Frequency of cankered } \\
\text { trees in infected stands }\end{array}$} \\
\cline { 2 - 4 } Effect & df & $\chi^{2}$ & $P$ & & $\chi^{2}$ & $P$ \\
\hline Aspect ${ }^{\mathrm{b}}$ & 4 & 12.7 & 0.013 & & 23.4 & 0.001 \\
Median $I_{n}{ }^{\mathrm{c}}$ & 1 & 16.5 & 0.001 & & 4.8 & 0.001 \\
Median $I_{n}$-aspect & 4 & 0.2 & 0.996 & & 3.1 & 0.550 \\
Elevation $(\mathrm{m})$ & 1 & 3.7 & 0.055 & & 2.0 & 0.160 \\
\hline
\end{tabular}

${ }^{\text {a }}$ Results based on logistic regression. Likelihood ratio statistics are of type 3 , which means that the contribution of each variable is computed after the others have been entered in the model.

${ }^{\mathrm{b}}$ Aspect classes are east and northeast; north and northwest; west and southwest; south and southeast; or flat topography.

${ }^{\mathrm{c}} I_{n}$ is an index indicating $P$. cinnamomi overwinter survival in trunk cankers of red oak trees (14).

TABLE 3. Incidence of ink disease caused by Phytophthora cinnamomi on red oak according to site aspect in stands with suitable winter climate ${ }^{a}$

\begin{tabular}{|c|c|c|c|c|}
\hline \multirow[b]{2}{*}{ Aspect $t^{b}$} & \multirow[b]{2}{*}{ Number } & \multicolumn{2}{|r|}{ Frequency of } & \multirow{2}{*}{$\begin{array}{c}\text { Index of } \\
\text { canker } \\
\text { development }{ }^{\mathrm{c}}\end{array}$} \\
\hline & & $\begin{array}{l}\text { Stands with } \\
\text { ink disease }\end{array}$ & $\begin{array}{l}\text { Cankered trees (in stands } \\
\text { with ink disease) }\end{array}$ & \\
\hline ENE & 22 & $55 \%$ & $7 \%$ & 1.3 \\
\hline NNW & 27 & $52 \%$ & $4 \%$ & 0.9 \\
\hline WSW & 15 & $70 \%$ & $18 \%$ & 1.1 \\
\hline SSE & 28 & $85 \%$ & $9 \%$ & 0.9 \\
\hline None & 79 & $53 \%$ & $9 \%$ & 1.0 \\
\hline
\end{tabular}

${ }^{a}$ Locations with $I_{n}$, an index indicating $P$. cinnamomi overwinter survival in trunk cankers of red oak trees (14), greater than 0.65 .

${ }^{\mathrm{b}}$ ENE, east and northeast; NNW, north and northwest; WSW, west and southwest; SSE, south and southeast; and None, flat topography.

${ }^{c}$ The index of canker development measures the volume loss on infected trees due to the canker.

TABLE 1. Comparison between modeled Phytophthora cinnamomi overwintering survival, $I_{n}$, and incidence of ink disease of red oak in southwest France

\begin{tabular}{|c|c|c|c|c|c|}
\hline \multirow[b]{3}{*}{ Median $I_{n}{ }^{\mathrm{a}}$} & \multirow{2}{*}{\multicolumn{2}{|c|}{ Number of stands }} & \multicolumn{2}{|c|}{ Frequency of } & \multirow{3}{*}{$\begin{array}{l}\text { Index of canker } \\
\text { development }^{\text {b }}\end{array}$} \\
\hline & & & \multirow{2}{*}{$\begin{array}{l}\text { Stand with ink } \\
\text { disease }(\%)\end{array}$} & \multirow{2}{*}{$\begin{array}{c}\text { Cankered trees } \\
(\%, \text { in stands with ink disease })\end{array}$} & \\
\hline & Total & With ink disease & & & \\
\hline$<0.55$ & 8 & 0 & 0 & $\ldots$ & $\ldots$ \\
\hline $0.55-0.65$ & 10 & 0 & 0 & $\ldots$ & $\ldots$ \\
\hline $0.65-0.70$ & 18 & 2 & 11 & $2 \pm 1$ & $1.0 \pm 0.1$ \\
\hline $0.70-0.75$ & 16 & 5 & 31 & $14 \pm 7$ & $1.3 \pm 0.2$ \\
\hline $0.75-0.80$ & 35 & 25 & 71 & $8 \pm 4$ & $1.1 \pm 0.2$ \\
\hline $0.80-0.85$ & 25 & 10 & 40 & $6 \pm 4$ & $0.8 \pm 0.2$ \\
\hline $0.85-0.90$ & 68 & 48 & 71 & $8 \pm 2$ & $1.0 \pm 0.2$ \\
\hline $0.90-0.95$ & 12 & 12 & 100 & $22 \pm 6$ & $1.2 \pm 0.1$ \\
\hline
\end{tabular}

${ }^{a}$ is an index indicating $P$. cinnamomi overwinter survival in trunk cankers of red oak trees (14).

b The index of canker development measures the volume loss on infected trees due to the canker. 
The distribution of the ink disease in southwest France shown in Figure 1 closely matches the distribution of the median $I_{n}$ (Fig. 5). Indeed, in both cases there is a west-to-east gradient in the Pyrenean Piedmont, from the Basque area, around Biarritz, to the east of Hautes-Pyrénées and south of Haute-Garonne. Also, median $I_{n}$ values are smaller north of the line from Bordeaux to Toulouse, and disease is absent in that area.

\section{DISCUSSION}

The median $I_{n}$ enabled us to adequately predict the distribution of the disease in southwest France. The simulation of canker
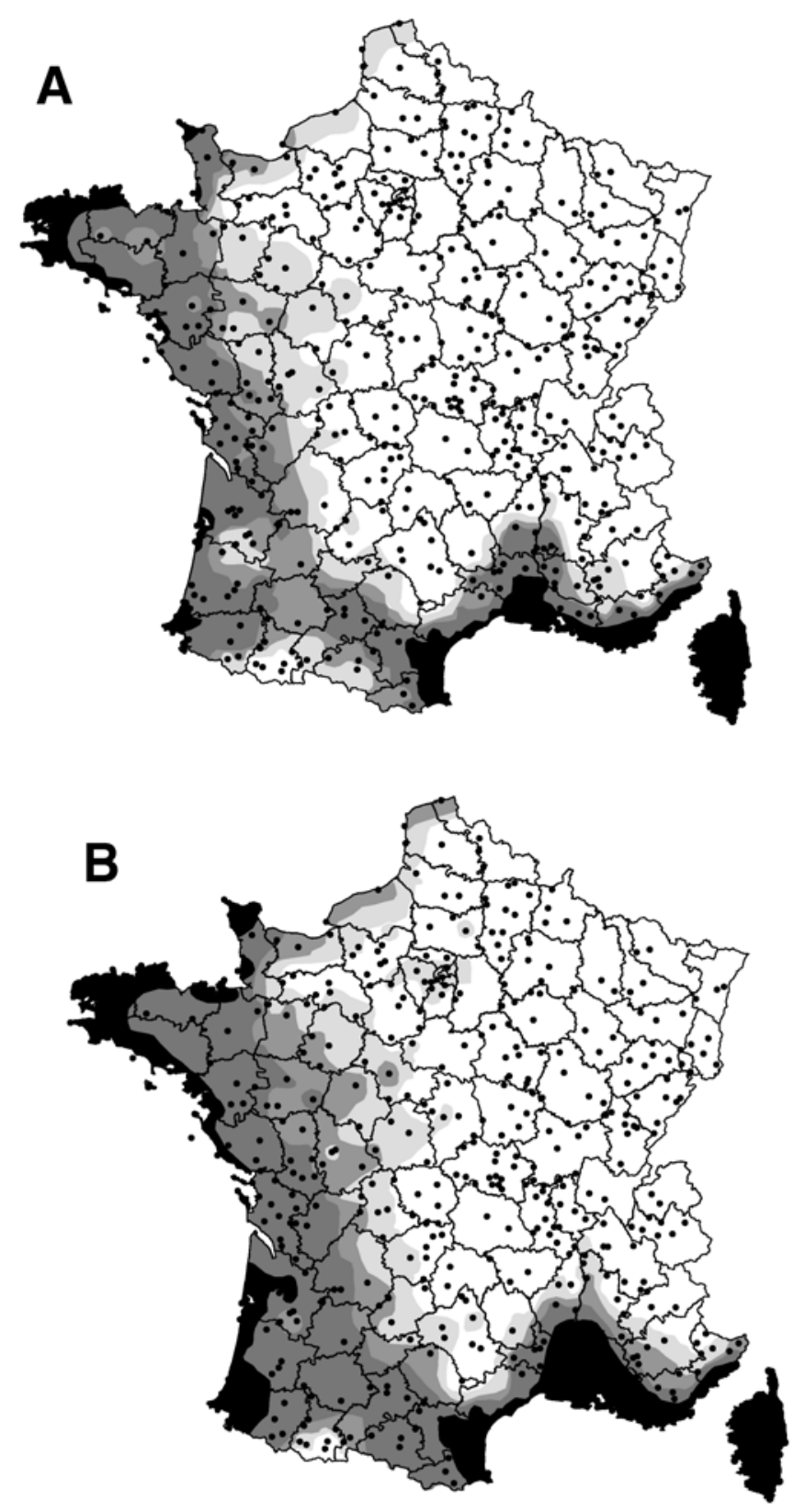

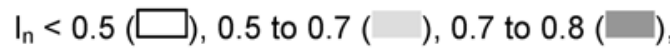

$$
\begin{aligned}
& 0.8 \text { to } 0.9 \text { ( } \square), \quad>0.9 \text { ( } \quad
\end{aligned}
$$

Fig. 5. Mapping of ink disease hazard in France, based on the median predicted survival of Phytophthora cinnamomi in oak trunks. A, Median $I_{n}$ for Quercus rubra. B, Median $I_{n}$ for $Q$. robur. $I_{n}$ is an index indicating overwinter survival of $P$. cinnamomi in oak cortical tissues. Closed circles represent meteorological stations used in the study. development predicted that cankers will fail to develop in areas where median $I_{n}$ is lower than about 0.5 to 0.6 , and indeed no disease is found in southwest France in stands where median $I_{n}$ is $<0.65$. The prediction was especially good for presence of disease in stands. The frequency of moderately cold winters was more important for preventing canker enlargement than the occasional occurrence of very severe frosts. Winter temperature regime appears to be the predominant factor in the distribution of ink disease in southwest France and, in particular, the west-to-east gradient in disease incidence that can be observed in the Pyrenean Piedmont. The Gers, Landes, and Lot-et-Garonne areas also have favorable winter temperature regimes. However, in these areas, the forest is mainly a pine forest and few red oak stands are present. As a consequence, the approach used in this work to estimate the suitability of climate for ink disease development as far as winter temperature regime is concerned can be considered valid.

Previous reports of the field survey $(10,11)$ indicated that disease incidence is linked to elevation: at elevations above $440 \mathrm{~m}$, no disease can be found. The hypothesis was that at higher elevations, winters are unfavorable to the survival of $P$. cinnamomi. Indeed, once the impact of frost was taken into account by the median $I_{n}$, elevation did not bring any additional information in our analysis. The lower incidence of the disease in stands on northern aspects might also have been linked to winter temperature conditions. However, there was no interaction between median $I_{n}$ and aspect: incidence of ink disease remains low on northern aspects even in the Basque area where winter temperature regime is almost never limiting for canker development, with $I_{n}>0.9$ for $>80 \%$ of the years. Alternatively, the difference in incidence of ink disease on different aspects could be linked to the water regime. The susceptibility of red oak to $P$. cinnamomi is increased by water stress (13). A higher incidence of ink disease on southerly aspects could be due to higher evapotranspiration during summer and more frequent water deficit. Indeed, the disease is also more severe on other locations that are prone to water deficit, i.e., hilltops and upper slopes compared with flat topography and lower slopes (10-12).

Our modeling approach only considers the ability of the pathogen to cause cankers once it is present at the tree basis. The underlying hypothesis is that the pathogen is introduced into forests by planting infected, nursery-raised oaks and is quite well distributed in infected stands. We thus did not consider the spread of the pathogen in soil within the stand. This assumption appears to be justified by the close agreement between ability of the pathogen to survive in trunk canker in a location and incidence of ink disease is this area. The mapping of disease hazard would also need to be improved by including other environmental effects that may act on canker enlargement at a regional scale such as temperature during the growing season. Such information would be important in particular in Brittany where summer temperature might not be high enough to enable proper canker development. Unfortunately, the variability in summer temperature was not high enough during the studied period in southwest France, and we did not have enough data to include this effect in the model. In any case, in locations where median $I_{n}$ was $<0.5$, the winter temperature regime was not favorable to the ink disease of red oak. For $I_{n}$ between 0.5 and 0.7 , the winter temperature regime was moderately unfavorable to the disease and its development should be strongly hampered. By contrast, in locations where median $I_{n}$ was $>0.7$, winter temperatures were not limiting for disease development.

The median $I_{n}$ was much better linked to the likelihood of disease presence in a stand than to frequency of cankered trees in infected stands. It appears that once climate enables some overwintering of $P$. cinnamomi in the tree cortical tissues, the development of the disease in some stands may be severe. It is likely that the local site conditions such as aspect, topography, and soil are then major factors determining the local incidence of the dis- 
ease (10-12), which explains the looser relationship with median $I_{n}$. It has to be pointed out that the relationship between $P_{n}$ and $I_{n} \times P_{n-1}$ was loose (Fig. 2), which suggests that many significant factors, in particular tree variability in susceptibility and site effects, were not taken into account.

Since soil seldom freezes at depths of $>10 \mathrm{~cm}$ in southwest France, $P$. cinnamomi is less exposed to temperature $<0^{\circ} \mathrm{C}$ in the soil than in trunks. Therefore, we anticipated that in areas with winter temperature regime moderately unfavorable to ink disease development on oak, very small cankers would occur resulting only from root infection each year. Thus, the first limiting effect of frost on disease would have been a limited canker height. However, frequent years with unfavorable winter temperature appeared to have an impact mainly on the proportion of trees cankered per stand. No relation could be seen with the canker size on infected trees. Other important stand factors such as aspect and topography were also shown to have a much higher impact on the proportion of cankered trees per stand than on canker size on infected trees $(10,11)$. Obviously, the establishment of $P$. cinnamomi on the lower bole of an oak tree is a key step in disease development. Perhaps in stands where frost limits disease incidence, only trees very susceptible to $P$. cinnamomi are cankered, whereas in stands where winter conditions are favorable to the disease, many trees with limited susceptibility to $P$. cinnamomi get cankered.

Climatic factors, especially winter temperature, may also explain the absence of ink disease of red oak in its natural range in the eastern United States. Indeed, severe $P$. cinnamomi damage has been reported on chestnuts and pines in the southern part of the red oak range. However, red oak, at those latitudes, is generally found at much higher elevations than chestnuts and pines (24). Mortality of chestnuts was especially high in bottomlands and at lower elevations (6).

To our knowledge, this is the first hazard mapping for a disease caused by $P$. cinnamomi, based on the modeling of a key epidemiological process, i.e., the winter survival of the parasite in trunks. $P$. cinnamomi has been known to be susceptible to frost for many years $(2,22)$ and other mappings have been based on correlation analysis and climate matching $(4,19)$. As expected, temperature, especially the minimum, was among the most discriminatory variables. Our results are in good agreement with the CLIMEX analysis performed by Brasier and Scott (4) for Europe. They show that the disease could develop in many areas of France where it is not present yet, especially in the west of the country. Moreover, high risk of ink disease on pedunculate oak could exist in a wider area than for red oak. It is therefore very important to avoid the introduction of $P$. cinnamomi in areas or stands presently free of the parasite, especially via infected nursery seedlings when plantations are established.

\section{ACKNOWLEDGMENTS}

The work was funded by the INRA program "AIP Ecopath" and by the French Ministry of Agriculture and Fishery (D.E.R.F.). We thank all the observers of the Département de la Santé des Forêts who carried out the field survey; F. Maugard who helped in doing the survey; A. Mezdour, G. Roux, and D. Tzanos for their contribution; and G. Capron for technical assistance.

\section{LITERATURE CITED}

1. Barriéty, L., Jacquiot, C., Moreau, C., and Moreau, M. 1951. La maladie de l'encre du chêne rouge (Quercus borealis). Rev. Pathol. Vég. Entomol. Agric. Fr. 30:253-262.
2. Benson, D. M. 1982. Cold inactivation of Phytophthora cinnamomi. Phytopathology 72:560-563.

3. Brasier, C. M., Robredo, F., and Ferraz, J. F. P. 1993. Evidence for Phytophthora cinnamomi involvement in Iberian oak decline. Plant Pathol. 42:140-145.

4. Brasier, C. M., and Scott, J. K. 1994. European Oak declines and global warming: A theoretical assessment with special reference to the activity of Phytophthora cinnamomi. EPPO Bull. 24:221-232.

5. Collett, D. 1991. Modelling Binary Data. Chapman \& Hall, London.

6. Crandall, B. S., Gravatt, G. F., and Ryan, M. M. 1945. Root disease of Castanea species and some coniferous and broadleaf nursery stocks caused by Phytophthora cinnamomi. Phytopathology 35:162-180.

7. Delatour, C. 1986. Le problème du Phytophthora cinnamomi sur le chêne rouge (Quercus rubra). EPPO Bull. 16:499-504.

8. Foex, M. E. 1941. L'invasion des chênes d'Europe par le blanc ou Oïdium. Rev. Eaux Forêts. 79:338-349.

9. Grente, J. 1961. La maladie de l'encre du Châtaignier. Ann. Epiphyt. 12:5-59.

10. Levy, A. 1995. L'encre du chêne rouge d'Amérique: Répartition en France, facteurs stationnels dans le piémont des Pyrénées occidentales. Cahiers Département de la Santé des Forêts ${ }^{\circ}{ }^{\circ}$, Minist. Agric. Pèche, Paris.

11. Levy, A. 2000. Ink disease of northern red oak caused by Phytophthora cinnamomi: Distribution in France, sites factors in the piémont of western Pyrénées. Pages 122-123 in: First international meeting on Phytophthoras in Forest and Wildland Ecosystems. E. M. Hansen and W. Sutton, eds. Grant Pass, Oregon.

12. Marçais, B. 1992. Influence de facteurs de l'environnement sur le développement de l'encre du chêne rouge (Quercus rubra L.), maladie provoquée par Phytophthora cinnamomi Rands. Thèse de l'Université de Nancy 1.

13. Marçais, B., Dupuis, F., and Desprez-Loustau, M. L. 1993. Influence of water stress on the susceptibility of red oak (Quercus rubra) to Phytophthora cinnamomi. Eur. J. For. Pathol. 23:295-305.

14. Marçais, B., Dupuis, F., and Desprez-Loustau, M. L. 1996. Modelling the influence of winter frosts on the development of the ink disease of oak, caused by Phytophthora cinnamomi Rands. Ann. Sci. For. 53:369-382.

15. Maugard, F. 1997. L'encre sur chêne pédonculé: Une inquiétude nouvelle dans le Sud-Ouest. La santé des forêts (France) en 1996. Département de la santé des Forêts, Minist. Agric. Pèche, Paris.

16. Moreau, M., and Moreau, C. 1951. Une grave affection nouvelle de la forêt française: La maladie de l'encre du chêne. CR Hebd. Acad. Sci. 232:2252-2253.

17. Morel, O., Robin, C., Vettraino, A. M., Vannini, A., Perlerou, C., and Diamandis, S. 2003. Ink disease distribution on sweet chestnut in France, Italy and Greece and Phytophthora species associated. Pages 260-262 in: 2nd IUFRO Working Party 7.02.09 Meeting. J. A. McComb, G. E. Hardy, and I. C. Tommerup, eds. Murdoch University, Australia.

18. Pardé, L. 1929. The regeneration of the American red oak in the Barres domain. Rev. Eaux Forêts. 66:567-570.

19. Podger, F. D., Mummery, D. C., Palzer, C. R., and Brown, M. J. 1990. Bioclimatic analysis of the distribution of damage to native plants in Tasmania by Phytophthora cinnamomi. Aust. J. Ecol. 15:281-289.

20. Robin, C., Desprez-Loustau, M. L., Capron, G., and Delatour, C. 1998. First record of Phytophthora cinnamomi on cork and holm oaks in southeastern France and evidence of pathogenicity. Ann. Sci. For. 55:869-883.

21. Robin, C., Desprez-Loustau, M. L., and Delatour, C. 1992. Spatial and temporal enlargement of trunk cankers of Phytophthora cinnamomi in red oak. Can. J. For. Res. 22:367-366.

22. Sauthoff, W. 1967. Niedere Temperaturen als begrenzender Faktor für die Lebensfähigkeit von Phytophthora cinnamomi Rands in mineralischen Böden [Low temperature as a limiting factor in the viability of Phytophthora cinnamomi in mineral soil]. Meded. Rijksfac. Landbouwwet. Gent 32:409-414.

23. Tainter, F. H., O'Brien, J. G., Hernàndez, A., Orozco, F., and Rebolledo, O. 2000. Phytophthora cinnamomi as a cause of oak mortality in the state of Colima, Mexico. Plant Dis. 84:394-398.

24. USDA. 1965. Sylvics of Forest Trees of the U.S. U.S. Dep. Agric. Handb. 271.

25. Vegh, I., and Bourgeois, M. 1975. Données préliminaires sur l'étiologie du dépérissement des conifères d'ornement dans les pépinières françaises; Rôle de Phytophthora cinnamomi Rands. Pepinier Hortic. Maraich 153:39-49. 